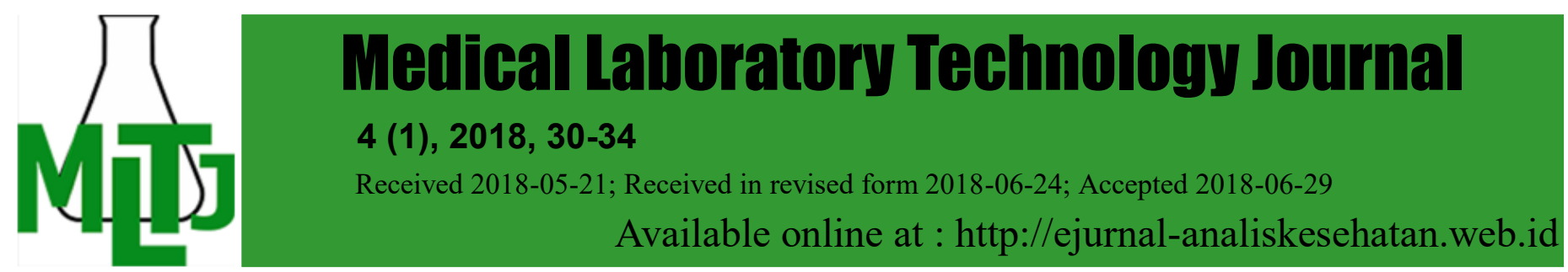

\title{
Staphylococcus aureus AND Methicillin resistant Staphylococcus aureus FROM THE DIABETIC ULCER
}

\author{
Leka Lutpiatina, Nisa Nur Agistni Eriana \\ Medical Laboratory Technology Poltekkes Kemenkes Banjarmasin \\ JI Mistar Cokrokusumo Street 4a Banjarbaru, Indonesia. \\ e-mail: leka.zns@gmail.com
}

\begin{abstract}
Infections of diabetic ulcers may occur because patients with diabetes mellitus have a weak immune system and the presence of high blood sugar into a strategic place for bacterial growth one of them is Staphylococcus aureus. Increased resistance of Staphylococcus aureus to various antibiotics, causing problems for the treatment of this infection. As by Methicillinresistant Staphylococcus aureus (MRSA) This study aims to assess the presence of Staphylococcus aureus and Methicillin-resistant Staphylococcus aureus (MRSA) at diabetic ulcer patient at Banjarmasin city hospital. This research uses descriptive observational research type. The study sample was patients with grade 2 and three diabetic ulcers with a total of 30 samples. The result of the research found 14 Staphylococcus aureus bacteria, Staphylococcus epidermidis nine, Staphylococcus saprophyticus two and 5 Gram-negative bacteria. Of the 14 samples of Staphylococcus aureus, there were eight samples of cefoxitin-resistant samples. The conclusion was $47 \%$ of Staphylococcus aureus in patients with a diabetic ulcer at Banjarmasin City Hospital. There was a $57 \%$ Methicillin-resistant Staphylococcus aureus in the isolated Staphylococcus aureus found. Need further research on the resistance of antibiotics oxacillin and cefoxitin to other Staphylococcus sp bacteria derived from patient diabetic ulcers.
\end{abstract}

Keywords: Methicillin resistant Staphylococcus aureus; diabetic ulcers

\section{INTRODUCTION}

Indonesia is a tropical country, where an infection is still the disease and the number one cause of death. Infection can occur in patients with diabetes mellitus who have open wounds or on diabetic ulcers. The prevalence of diabetic ulcer patients in Indonesia is about $15 \%$ with a mortality rate of $32 \%$, as well as the cause of hospital treatment with the most $80 \%$ for diabetes mellitus (Pendsey, 2010).

Infection can occur because diabetes mellitus patients have a weak immune system and high blood sugar to be a strategic place for bacterial growth one of them is Staphylococcus aureus (Hastuti, 2008). The results of Akhi et al. (2015), stated that the infection in diabetic ulcer sufferers caused by polymicrobial consisting of aerobic bacteria one of them is Staphylococcus aureus (28\%).

Staphylococcus aureus in the hospital may contaminate the surrounding environment including medical devices such as stethoscopes (Lutpiatina, L., 2017) and possibly infect patients. Hospital-staphylococcus aureus may be resistant to some antibiotics, but more sensitive to natural ingredients such as bee propolis (Lutpiatina, L., 2015) and leaf kenikir (Cosmos caudatus Kunth.) (Lutpiatina, L., Nur Rizqi Amaliah, Ratih Dewi Dwiyanti, 2017).

The abundance of irrational antibiotics is one of the main factors of antibiotic resistance (Sun et al., 2011). People infected with antibiotic-resistant microorganisms are a more frequent hospital and require treatment with second or third-choice drugs that may be less effective, more toxic and costly. Is further exacerbated by data showing that approximately 23,000 people die each year due to the bacterial infection that has been resistant to antibiotics (Sun et al., 2011).

The prevalence of antibiotic resistance increases every year. Based on a survey conducted by the Centers for Disease Control and Prevention (CDC) in 2013 in the United States, every year at least 2 million people are exposed to bacterial infections that are resistant to one or more types of antibiotics. 
Based on World Health Organization (WHO) data in 2009, Indonesia ranks 8th out of 27 countries with high burden of antibiotic resistance to Multi-Drug Resistance (MDR) bacteria in the world.

Staphylococcus aureus strains that have been resistant to antibiotic activity are among the $\beta$-lactam groups, including the penicillinase-resistant penicillins (oxacillin, methicillin, nepheline, cloxacillin, dicloxacillin), cephalosporins, and carbapenem groups (Yuwono, 2012). Result of Mutia (2010) research at Ulin Banjarmasin Hospital, found the resistance of Staphylococcus aureus bacteria to cephalosporin group antibiotic. The results of Meta et al. (2014) found bacteria Methicillin-resistant Staphylococcus aureus (MRSA) from diabetic ulcers of degree I and II in the disease in RSUD Arifin Achmad as many as five samples $(83.33 \%)$.

It known that the resistance of Staphylococcus aureus to cephalosporin, cephalexin and cefotaxime antibiotics based on Mutia (2010) study at Banjarmasin City Hospital, but in CLSI standard (2017) stated that used as the standard test of $\beta$-lactam resistance group are oxacillin and cefoxitin. Both of these antibiotics are also the basis for the identification of methicillin-resistant Staphylococcus aureus (MRSA) bacteria, so it is to research the resistance of Staphylococcus aureus derived from diabetic ulcers against $\beta$-lactam group antibiotics using oxacillin and cefoxitin discs. The purpose of this study was to assess the presence of Staphylococcus aureus and Methicillin-resistant Staphylococcus aureus (MRSA) in patients with diabetic ulcers in Banjarmasin city hospitals.

\section{MATERIALS AND METHODS}

The type of research used in this research is descriptive observational. The sample of the study was diabetes mellitus patients who had body wounds or diabetic ulcers who examined in Banjarmasin city hospital. Sampling technique by purposive sampling that is wound swab patient of diabetes mellitus grade 2 and 3.

Isolation and identification of Staphylococcus aureus bacteria have taken from patients' diabetic ulcer swabs by planting on agar and Mannitol Salt Agar agar medium (Merck). Staphylococcus aureus has fermented mannitol to form a yellow colony and change the col-

or of the media to yellow. Gram stain has been performing on colonies grown on Mannitol Salt Agar medium; Staphylococcus aureus is a purple gram-positive $(+)$ bacteria with a clustered shaped form like grapes. A biochemical test of the confectionary medium has been performing, Staphylococcus aureus fermenting glucose and mannitol. Staphylococcus aureus positive $(+)$ catalase test. Coagulase Staphylococcus aureus positive (+) test.

Antibiotic resistance test using Kirby and Bauer method using Mueller Hinton (Merck) medium with $10 \mu \mathrm{g}$ oxacillin disc and $30 \mu \mathrm{g}$ cefoxitin (Clinical Laboratory Standards Institute(CLSI), 2017).

\section{RESULTS AND DISCUSSION}

This study conducted on 30 patients with type II diabetes mellitus who perform examination and treatment of wounds in Diabetic Foot Poly. Characteristics of respondents can be seen in table 1 as follows.

Table 1. Characteristics of Diabetes Mellitus Patients

\begin{tabular}{lcc}
\hline \multicolumn{1}{c}{ Research subject } & Frekuensi (N) & $\begin{array}{l}\text { Persentase } \\
(\%)\end{array}$ \\
\hline Gender & 12 & 40 \\
Man & & \\
Women & & 10 \\
Age & 3 & 23,33 \\
$33-43$ & 7 & 43,34 \\
$44-53$ & 13 & 23,33 \\
$54-63$ & 7 & 30 \\
$64-73$ & & 70 \\
Wound Classification & 9 & \\
Grade 2 & 21 & 23,33 \\
Grade 3 & & 76,67 \\
Patient Status & 7 & \\
Inpatient & 23 & \\
Outpatient & & \\
\hline
\end{tabular}

The result of bacteria identification on diabetic ulcus samples found 14 Staphylococcus aureus bacteria, Staphylococcus epidermidis of 9, Staphylococcus saprophyticus as much as two, and Gram-negative bacteria of 5 samples can be seen in the graph as follows

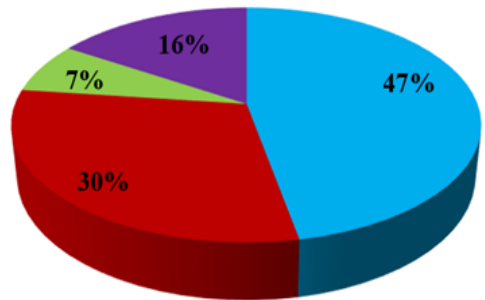

- Staphylococcus aureus

Chart 1. Result of Bacterial Identification on Sample of Diabetic Ulcer 
Table 2. Results of Resistance Examination on Staphylococcus aureus Isolates from Diabetic Ulcers

\begin{tabular}{cccc}
\hline No & $\begin{array}{c}\text { Code } \\
\text { Isolates }\end{array}$ & $\begin{array}{c}\text { Zona Hambat } \\
\text { Oxacilin } \\
\mathbf{1 0} \boldsymbol{\mu g}\end{array}$ & $\begin{array}{c}\text { Cefoxitin } \\
\mathbf{3 0} \boldsymbol{\mu g}\end{array}$ \\
\hline 1 & 003 & $24 \mathrm{~mm}$ & $20 \mathrm{~mm}(\mathrm{R})$ \\
2 & 004 & $19 \mathrm{~mm}$ & $9 \mathrm{~mm}(\mathrm{R})$ \\
3 & 006 & $26 \mathrm{~mm}$ & $21 \mathrm{~mm}(\mathrm{R})$ \\
4 & 009 & $40 \mathrm{~mm}$ & $32 \mathrm{~mm}(\mathrm{~S})$ \\
5 & 011 & $27 \mathrm{~mm}$ & $29 \mathrm{~mm}(\mathrm{~S})$ \\
6 & 012 & $7 \mathrm{~mm}$ & $15 \mathrm{~mm}(\mathrm{R})$ \\
7 & 013 & $23 \mathrm{~mm}$ & $25 \mathrm{~mm}(\mathrm{~S})$ \\
8 & 015 & $20 \mathrm{~mm}$ & $14 \mathrm{~mm}(\mathrm{R})$ \\
9 & 016 & $17 \mathrm{~mm}$ & $13 \mathrm{~mm}(\mathrm{R})$ \\
10 & 018 & $28 \mathrm{~mm}$ & $30 \mathrm{~mm}(\mathrm{~S})$ \\
11 & 021 & $6 \mathrm{~mm}$ & $19 \mathrm{~mm}(\mathrm{R})$ \\
12 & 025 & $25 \mathrm{~mm}$ & $31 \mathrm{~mm}(\mathrm{~S})$ \\
13 & 026 & $17 \mathrm{~mm}$ & $22 \mathrm{~mm}(\mathrm{~S})$ \\
14 & 029 & $7 \mathrm{~mm}$ & $19 \mathrm{~mm}(\mathrm{R})$ \\
\hline
\end{tabular}

Cefoxitin resisten $\leq 21 \mathrm{~mm}$, sensitive $\geq 22 \mathrm{~mm}$ R (Resisten), S (Sensitif)

Chart 1 shows $47 \%$ of Staphylococcus aureus. What the high infection of diabetic wounds caused by Staphylococcus aureus bacteria can cause by this bacteria is flora of the skin, so if an open wound will become the entrance of bacteria and can cause infection if it can not control. Staphylococcus aureus can produce $\beta$ lactamase, which will hydrolyze the bonds on the antibiotic-lactam molecule $\beta$ lactam ring and result in antimicrobial inactivation resulting in resistance to antibiotics (Pratiwi, 2008). Infection caused by Staphylococcus aureus could be more if it caused by an antimicrobial-resistant strain (Monecke, 2011).

Incidence of resistance to diabetic wounds may have an effect on length of hospitalization, affecting morbidity and mortality (Radji et al., 2014). MRSA from hospitals and (Radjer external environments is a concern for Ad public health (Gould S. W. J. 2010, Deurenberg R. H. 2007)

Table 2 shows the results of cefoxitin resistance as much as $57 \%$. Indicates that there is a $57 \%$ MRSA in Staphylococcus aureus isolates found in this study. Clinical Laboratory Standards Institute (CLSI) in 2017 states to detect MRSA using cefoxitin. The results of diffusion of cefoxitin discs (resistant $\leq 21 \mathrm{~mm}$, sensitive $\pm 22 \mathrm{~mm}$ ) can be used to predict the presence of Staphylococcus aureus with the MecA gene, whereas for oxacillin it is not recommended to use disc diffusion results but can use minimal inhibitory concentrations (MIC). This study used the disc diffusion method for both antibiotics, so the oxacillin inhibitory results were not seen by CLSI recommendations 2017. Other studies also suggest that cefoxitin disc diffusion assays are recommended for MRSA routine detection and are considered a better indicator of oxacillin (Ibrahim, $\mathrm{O}$. M. A., Bilal, N. E., Osman, O. F., \& Magzoub, M. A.2017, RW Smyth 2005, Mimica MJ., 2007).

Similar studies conducted by Adhikari R. et al. (2017) were on wound swabs with a yield of $15.47 \%$ found in Staphylococcus aureus, of which $39(35.50 \%)$ isolates were identified as MRSA by disc diffusion method of cefoxitin. According to Baddour M. M (2006), Koyama N. (2012), Rehm S. J. (2008), Torimiro N (2013) MRSA is resistant to all $\beta$-lactam classes including cephalosporins and carbapenems. MRSA resistance may develop in quinolones, aminoglycosides, and higher macrolides.

MRSA formed by the presence of mecA gene, a meticillin-resistant encoding found in Staphylococcus aureus. This resistant gene encodes Penicillin Binding Protein 2a (PBP 2a) which does not bind meticillin as it should. (Ito T., 2001, Grundmann H. 2006). MRSA infections require relatively more difficult, and higher maintenance, so accurate and rapid MRSA identification is essential (Johnson A. P. 2011).

\section{CONCLUSION}

There is $47 \%$ of Staphylococcus aureus in patients with the diabetic ulcer in Banjarmasin City Hospital. There was a $57 \%$ Methicillinresistant Staphylococcus aureus in the isolated Staphylococcus aureus found.

\section{REFERENCES}

Adhikari, R., Pant, N. D., Neupane, S., Neupane, M., Bhattarai, Roshan, ... Lekhak, B. (2017). Detection of Methicillin Resistant Staphylococcus aureus and Determination of Minimum Inhibitory Concentration of Vancomycin for Staphylococcus aureus Isolated from Pus/Wound Swab Samples of the Patients Attending a Tertiary Care Hospital in Kathmandu, Ne. Can J Infect Dis Med Microbiol, 2017. 
Akhi M.T., Ghotaslou R., Asgharzadeh M., Koyama N., Inokoshi J., Tomoda H. (2012). Varschochi A.M., Pirzadeh. T. and Memar. M. (2015). Bacterial Etiology and Antibiotic Susceptibility Pattern of Diabetic Foot Infections in Tabriz Iran. GMS Hygiene and Infection Control, 10, 1-6.

Baddour M. M., Abuelkheir M. M., Fatani. A. J. (2006). Trends in antibiotic susceptibility patterns and epidemiology of MRSA isolates from several hospitals in Riyadh, Saudi Arabia. Annals of Clinical Microbiology and Antimicrobials, 5.

Clinical and Laboratory Standards Institute Lutpiatina, L., Amaliah, N. R., \& Dwiyanti, R. (CLSI). (2017). M100, 27th ed.Performance Standards for Antimicrobial Susceptibility Testing.

Deurenberg R. H., Vink C., Kalenic S., Friedrich A. W., Bruggeman C. A., Stobberingh. E. E. (2007). The molecular evolution of methicillin-resistant Staphylococcus aureus. Clinical Microbiology and Infection, 13(3), 222-235.

Gould S. W. J., Cuschieri P., Rollason J., Hilton A. C., Easmon S., Fielder M. D. (2010). The need for continued monitoring of antibiotic resistance patterns in clinical isolates of Staphylococcus aureusfrom London and Malta. Annals of Clinical Microbiology and Antimicrobials, 9.

Grundmann H., Aires-de-Sousa M., Boyce J., T Tiemersma E. (2006). Emergence and resurgence of methicillin-resistant Staphylococcus aureus as a public threat. The Lancet Infectious Diseases, 368, 874885.

Anti-infectious agents against MRSA. Molecules, 18(1), 204-224.

Lutpiatina, L. (2015). Efektivitas Ektrak Propolis Lebah Kelulut (Trigona spp) Dalam Menghambat Pertumbuhan Salmonella typhi, Staphylococcus aureus dan Candida albicans. J. Skala Kesehatan, 6(1).

Lutpiatina, L. (2017). Cemaran Staphylococcus aureus dan Pseudomonas aerogenosa Pada Stetoskop dirumah sakit. J. Teknol. Lab, 6(2).

D. (2017). Daya Hambat Ekstrak Daun Kenikir (Cosmos caudatus Kunth.) terhadap Staphylococcus aureus. Meditory, 5(2), 83-91.

Meta, D. T., Endriani, R., \& Sembiring, L. P. (2014). Definov Tacsa Meta, Rita Endriani, Ligat Pribadi Sembiring. 2014. Identifikasi dan Resistensi Bakteri Metchilin resistant Staphylococcus aureus (MRSA) dari Ulkus Diabetikum Derajat I dan II Wagner Di Bagian Penyakit Dalam RSUD Arifin Achmad. Jurnal Peneli. Jurnal Penelitian Fakultas Kedokteran Universitas Riau.

Mimica M.J.; Berezin E.N.; Carvalho R.L.B.; Mimica I.M.; Mimica L.M.J.; Sáfadi M.A.P.; Schneider E.; Caiaffa-Filho H.H. (2007). Detection of methicillin resistance in Staphylococcus aureus isolated from pediatric patients: is the cefoxitin disk diffusion test accurate enough? Braz J Infect Dis, 11(4).

Hastuti, T. R. (2008). Faktor-Faktor Resiko Monecke S., Coombs G., S. A. C. (2011). A Ulkus Diabetika Pada Penderita Diabetes Mellitus. Semarang.

Ibrahim, O. M. A., Bilal, N. E., Osman, O. F., \& Magzoub, M. A. (2017). Assessment of methicillin resistant Staphylococcus Aureus detection methods: analytical comparative study. The Pan African Medical Journal, 27(281).

Ito T., Katayama Y., Asada K. (2001). Structural comparison of three types of staphylococcal cassette chromosome mec integrated in the chromosome in methicillinresistant Staphylococcus aureus. Antimicrobial Agents and Chemotherapy, 45(5), 1323-1336.

Johnson A. P. (2011). Methicillin-resistant field guide to pandemic, epidemic and sporadic clones of methicillin-resistant Staphylococcus aureus. PLoS ONE, 6(4).

Pendsey S.P. (2010). Understanding Diabetic Foot. International Journal of Diabetes in Developing Countries, 30(2), 75-79.

R. W. Smyth, Gunnar K. (2005). Mannitol Salt Agar-Cefoxitin Combination as a Screening Medium for Methicillin-Resistant Staphylococcus aureus. J. Clin. Microbiol, 43(8), 3797-3799.

Rehm S. J. (2008). Staphylococcus aureus: the new adventures of a legendary pathogen. Cleveland Clinic Journal of Medicine, 75(3), 177-192. Staphylococcus aureus: the European landscape. Journal of Antimicrobial Chemotherapy, 66(S4). 
Sun, T., et al. (2011). The imoact of psychological capital on job embeddedness and job performance among nurse : A structural equation approach. Journal of Advance Nursing, 61.

Sylvia T, Pratiwi. (2008). Mikrobiologi Farmasi. Yogyakarta: Erlangga.

Torimiro N. (2013). Analysis of Beta-lactamase production and antibiotics resistance in Staphylococcus aureus strains. Journal of Infectious Diseases and Immunity, 5(3), 24-28.

Yuwono. (2012). Staphylococcus aureus dan Methicilin-Resistant Staphylococcus aureus (MRSA). Departemen Mikrobiologi FK Unsri Palembang.

Zainun, M. (2010). Uji Resistensi Antibiotik Chepalexin dan Cefotaxim terhadap Bakteri Staphylococcus aureus di RSUD Ulin Banjarmasin. Jurusan Analis Kesehatan Poltekkes Banjarmasin. 